\title{
Management of Apple Scab and Powdery Mildew Using Bicarbonate Salts and Other Alternative Organic Products with Fungicide Effect in Apple Cultivars
}

\author{
Viorel MITRE ${ }^{1}$, Erzsébet BUTA ${ }^{1}$, Lehel LUKÁCS², \\ Ioana MITRE ${ }^{1 *}$, Răzvan TEODORESCU ${ }^{3}$, Dorel HOZA³ \\ Adriana F. SESTRAȘ ${ }^{1}$, Florin STĂNICA $\breve{A}^{3}$ \\ ${ }^{1}$ University of Agricultural Sciences and Veterinary Medicine, Faculty of Horticulture, 3-5 Mănăștur Street, 400372 Cluj-Napoca, Romania; \\ viorel.mitre@usamvcluj.ro; adriana.sestras@usamvcluj.ro; ebuta2008@yahoo.com;ioanamitre@yahoo.com (*correspondingauthor) \\ ${ }^{2}$ Fruit Research Station Cluj, 5 Horticultorilor Street, 400457 Cluj-Napoca, Romania; lehel_lukacs@yahoo.com \\ ${ }^{3}$ University of Agronomic Sciences and Veterinary Medicine Bucharest, 59 Mărăşti Blvd, District 1, 011464, Bucharest; \\ Romania; razvan.iteodorescu@gmail.com;dorel.hoza@gmail.com;flstanica@yahoo.co.uk
}

\begin{abstract}
The control of apple scab and powdery mildew is a challenge for organic fruit growing. Bicarbonate salts are already consecrate in reducing the attack of scab and powdery mildew in organic apple culture. In the current study the influence of some products accepted in organic apple production to control scab and powdery mildew (potasium bicarbonate, lime sulphur, wettable sulphur, potassium silicate, cooper ammonium-phosphate, potassium bicarbonate + potassium silicate, potassium bicarbonate + wettable sulphur) in comparison with untreated control, were used. The biological material was represented by three scab resistant cultivars ('Luna', 'Topaz' and 'Sirius') and three scab susceptible cultivars ('Elstar', 'Pinova' and 'Golden Delicious'). The experiments were carried out during 2014-2016 at Steluța LTD, Cluj-Napoca, N.W. Romania, as a bifactorial experiment arranged in randomized blocks. The trees were planted in 2011 at a density of 3,175 trees/ha. Depending of the year, a number of 18-22 treatments were made annually after each rain. It can be concluded that the combination of potassium bicarbonate + wettable sulphur significantly reduced the attack degree of scab and powdery mildew on leaves and fruits and increased the yield of the scab-susceptible and scab resistant cultivars. Good results were obtained in the case of treatment with potassium bicarbonate with potassium silicate, potassium bicarbonate and cooper ammonium phosphate. The treatments with the products used in the experiments did not register symptoms of phytotoxicity on leaves or fruits, except lime sulphur and wettable sulphur and cooper ammonium phosphates.
\end{abstract}

Keywords: apple, bicarbonate, organic, powdery mildew, scab

\section{Introduction}

In the last decades, organic apple crop is constantly expanding, and the demand for healthy apples, with no chemical residual products, is increasing. For organic apple growers, the biggest challenge is scab and powdery mildew diseases control.

Most commercial apple grown cultivars are very sensitive to scab, so that in an commercial apple orchard, very frequent fungicide applications (15-22 annually) are applied in order to control apple scab, depending on weather conditions, disease pressure and cultivar susceptibility (Holb et al., 2005).
In organic apple growing, just a few approved chemical products are available for disease control, mainly based on sulphur and copper (Holb, 2008); various natural plant extracts containing triterpenoid saponins, polyphenols and specific flavonoids have been reported to have antifungal properties (Köhl et al., 2007; Bahraminejad et al., 2008; Bengstsson et al., 2009; Jamar et al., 2010).

Another way to control these diseases could be the cultivation of low scab-susceptible or scab-resistant cultivars having the $V f$ gene. However, new scab races, virulent to the $V f$ gene, have appeared in most European countries (Gessler et al., 2006). Consequently, monogenic, polygenic and incorporated monogenic + polygenic resistance needs to be 
116

carefully integrated into anti-breakdown strategies (Jamar et al., 2010; Sestras et al., 2011; Dan et al., 2015).

The use of copper as fungicide in organic apple is often disputed even if the copper as fungicide is effective, persistent, highly active, cheap and covers a well-known number of fungal diseases.

Over the years, using of copper-based compounds especially in high quantities is leading to an accumulation of copper in the orchard soil over of official limit in Europe of $36 \mathrm{mg} \mathrm{kg}^{-1}$ soil). More than that, in some European countries (Nederland and the Scandinavian countries) using of cooper based products is forbidden.

Therefore, the chemical option for apple scab control in organic farming is the use of elemental sulphur and lime sulphur products (Holb et al., 2003).

Elementary sulphur and sulphur based compounds often have less curative proprieties against scab and powdery mildew than copper-based compounds, especially in cold weather (unless lime sulphur).

Several studies have shown that the repeated application of large amounts of sulphur compounds has eco toxicological and phytotoxic side-effects (Mills, 1947; Kreiter et al., 1998; Holb et al., 2003; Palmer et al., 2003).

Unfortunately, lime sulphur can be injurious to the trees, lowering photosynthesis rates, reducing fruit set, fruit yield and pollen germination, inducing phytotoxic burns on leaves and fruits, affecting fruits quality (MacDaniels and Furr, 1930; Burrell, 1945; MacHardy, 1996; Palmer et al., 2003; Environmental Protection Agency, 2006; McArtney et al., 2006; Cromwell et al., 2011).

Due to the negative fungal properties of the standard sulphur/lime sulphur fungicides in organic apple production, it is necessary to evaluate the effectiveness of other alternative, organically approved or proposed to approval fungicides (Creemers et al., 2006).

The efficacy of bicarbonate salts in the control of these diseases was known many years ago (Marloth, 1931). Efficacy of bicarbonate salts is the focus of scientific worldwide research. The mode of bicarbonate salts action is bound to the perturbation of $\mathrm{pH}$, osmotic pressure, the bicarbonate/carbonate ion balance of sensitive fungi and these salts acts by contact to fungi in aqueous solution and inhibits the development of fungal mycelium (Marku et al., 2014).

The aims of this 3-year study were to evaluate the effectiveness of bicarbonate salts and other alternative organic products with fungicide effect, alone or mixed (wettable sulphur, lime sulphur, potassium bicarbonates, potassium silicate and copper) in apple scab and powdery mildew control. In addition, their phytotoxicity and effects of these products on yield and fruit quality on cultivars with varying degrees of resistance and sensitivity to these diseases were investigated.

\section{Materials and Methods}

\section{Location and orchard density}

The research has been carried out in a commercial apple orchard with a density of 3,175 trees/ha (trees were planted at a distances of $3.5 \times 0.9 \mathrm{~m}$ ) established in 2011 belonging to Steluța LTD, Cluj-Napoca, Transylvania (N.W. Romania), in 2014-2016.

\section{Plant material}

Plant material was represented by three scab resistant cultivars ('Luna', 'Topaz' and 'Sirius') and three scab susceptible cultivars ('Elstar', 'Pinova' and 'Golden Delicious'). The growing technology was specific to apple super-intensive orchards. The trees have not been maintained according to organic production standards, excepting the control of scab and powdery mildew.

In Table 1 are presented the information about the products, alone or mixed, used in the experiment (trademark, active ingredient, dose).

\section{Cultural management of the plantation}

First treatments were applied just before or at the beginning of the infection risk periods. Depending of the year, a number of 18-22 treatments were made annually, after each rain, immediately after rain stopped. Each treatment combination was applied in each block after each rain, during all period of the infection process. All treatments were applied at a low spray rate of $500 \mathrm{l} \mathrm{ha}^{-1}$.

Potassium and silicon based products and copper ammonium phosphate were prepared in collaboration with the Faculty of Chemistry, Cluj-Napoca, Romania: potassium bicarbonate solution had a concentration of $20 \%$ and potassium silicate $30 \%$.

\section{Experimental design}

The experiment was bifactorial, set up in randomized blocks, the first factor being the treatment with eight

Table 1. Treatments and active ingredients application rates

\begin{tabular}{|c|c|c|}
\hline Trademark & Active ingredient & Dose ha $^{-1}$ \\
\hline Control & no treatment & - \\
\hline Potassium bicarbonate + Potassium silicate & Potassium bicarbonate (20\%) + Potassium silicate (30\%) & $\begin{array}{l}2.5 \mathrm{ha}^{-1} \text { Potassium bicarbonate } \\
+0.5 \mathrm{~kg} \mathrm{ha}^{-1} \text { Potassium silicate }\end{array}$ \\
\hline Lime Sulphur & Calcium polysulphide $1 \%$ & $5 \mathrm{~kg} \mathrm{ha}^{-1}$ \\
\hline Potassium Bicarbonate & Potassium bicarbonate $(20 \%)+$ & $5 \mathrm{~kg} \mathrm{ha}^{-1}$ Potassium bicarbonate \\
\hline + Thiovit jet (Syngenta Agro, Fr.) & Wettable sulphur $(80 \%)$ & $+2 \mathrm{~kg} \mathrm{ha}^{-1}$ Wettable sulphur \\
\hline Potassium silicate & Potassium silicate $(30 \%)$ & $2.6 \mathrm{~kg} \mathrm{ha}^{-1}$ \\
\hline Thiovit jet (Syngenta Agro, Fr.) & Wettable sulphur $(80 \%)$ & $4 \mathrm{~kg} \mathrm{ha}^{-1}$ \\
\hline Potassium bicarbonate & Potassium bicarbonate $(85 \%)$ & $5 \mathrm{~kg} \mathrm{ha}^{-1}$ \\
\hline $\begin{array}{l}\text { Cooper ammonium } \\
\text { phosphate }\end{array}$ & Copper hydroxide ( $40 \%)$ & $300 \mathrm{~g} \mathrm{ha}^{-1}$ \\
\hline
\end{tabular}


graduations: control (untreated), mixture between potassium bicarbonate and potassium silicate, lime sulphur, mixture between potassium bicarbonate and wettable sulphur, potassium silicate, wettable sulphur, potassium bicarbonate, cooper ammonium phosphate. The second factor was the cultivar with six graduations, thus resulting in 48 variants, in three replications ( 3 trees / replication).

\section{Observation and measurements}

Each year, diseases assessments on the leaves and fruits were made. Visual observations in the field were made on the intensity and frequency attack of apple scab and apple powdery mildew on leaves, the intensity and frequency attack of scab on fruits and phytotoxicity on leaves and fruit. Fruit scab intensity and fervency attack of infection was calculated as the proportion of total harvested fruit with at least one scab lesion.

\section{Statistical analysis}

Data processing was done by means of the analysis of variance (ANOVA test) and the interpretation of results was performed through Duncan test.

\section{Results and Discussion}

\section{The influence of environmental conditions}

Environmental conditions, especially temperature and precipitations, have a strong influence on triggering primary and secondary infections with scab and powdery mildew in the apple orchards. The number of annual necessary treatments against these diseases is depending on weather conditions, disease pressure and cultivar susceptibility (Holb et al., 2005). The monthly and annual mean values of temperature during 2014-2016 presented in the Fig. 1 express differences between monthly mean values from one year to another. The highest temperature values were in August 2015 and the lowest in January 2015, all being over to the multiannual average values of temperature for the study area.

The rainiest year within the study interval was 2015, when the pressure of infection was also the highest one. However, the differences between values of average monthly precipitations sum were not too big from one year to another (Fig. 2). The climatic conditions of the three years of experience were favorable to development of apple scab

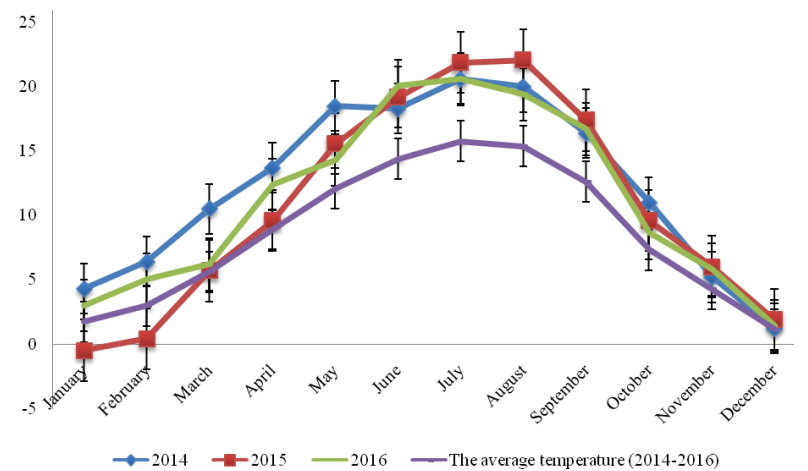

Fig. 1. Averages of monthly and annual temperatures in the experimental field during 2014-2016 and powdery mildew; actually, Transylvania region is a favorable one for development of these apple diseases, even in conventional orchards.

The influence of different products against apple scab attack, on leaves

Regardless the cultivar, between the seven variants of treatments and control there were differences statistically assured (Table 2).

Usage of treatments with bicarbonate salts determined a reduction of the attack degree of 2-6.5 times. Even more, all other products used in the experiment reduced the attack degree compared to the control variant. The most efficient spray treatment was recorded in the variant with potassium bicarbonate + wettable sulphur $(3.4 \%$ ad), followed by the variant potassium bicarbonate + potassium silicate $(4.6 \%$ ad), compared to the control $(21.6 \%$ ad). Good results were obtained also in the case of lime sulphur variant, followed by the variants with cooper ammonium phosphate, potassium silicate and wettable suphur.

Regardless the influence of treatment, between cultivars sensitive to scab and the cultivars resistant to scab and between cultivars sensitive to scab themselves, differences statistically assured were registered. Among the cultivars susceptible for apple scab, the lowest value of attack degree was obtained for 'Pinova' (14.7 \%), followed by 'Elstar' (19.5\%). During the 3 years of the experiment, there were no symptoms of apple scab observed on the leaves of any of the scab-resistant cultivars under study.

The influence of different products against apple scab attack, on fruits

Regarding the scab attack on fruits, it can be observed that all treatments strongly reduced the attack degree (Table 3). The highest pressure of infection value was recorded at 'Golden Delicious' (16.2\%) followed by 'Elstar' and 'Pinova'. The scab resistant cultivars behaved similarly from the statistically point of view, without scab infection symptoms.

Irrespective of cultivars, the best treatment in reducing scab attack degree on fruits was the mixture between potassium bicarbonate and wettable sulphur, respectively, the mixture potassium bicarbonate + potassium silicate. All products used in the experience gave better results than the untreated control variant.

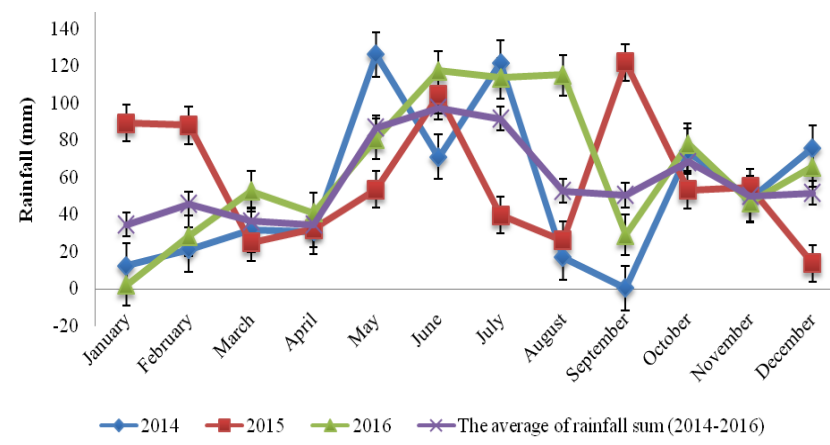

Fig. 2. The average monthly precipitations for each year of study and the average of rainfall sum in the experimental field during 2014-2016 
Table 2. Influence of different products recommended in organic apple growing against scab attack (AD \%) on leaves

\begin{tabular}{|c|c|c|c|c|c|c|c|}
\hline Treatment / Cultivar & 'Elstar' & 'Pinova' & 'Golden Delicious' & 'Luna' & 'Topaz' & 'Sirius' & $\begin{array}{c}\text { Mean } \\
\text { treatment }\end{array}$ \\
\hline Control & $42.4^{1}$ & $38.2^{k}$ & $49.0^{\mathrm{m}}$ & $0.0^{\mathrm{a}}$ & $0.0^{\mathrm{a}}$ & $0.0^{\mathrm{a}}$ & $21.6^{\mathrm{R}}$ \\
\hline $\begin{array}{l}\text { Potassium bicarbonate + } \\
\text { Potassium silicate }\end{array}$ & $8.2^{c}$ & $7.9^{\mathrm{c}}$ & $11.5^{\mathrm{d}}$ & $0.0^{\mathrm{a}}$ & $0.0^{\mathrm{a}}$ & $0.0^{\mathrm{a}}$ & $4.6^{\mathrm{M}}$ \\
\hline Lime Sulphur & $18.9^{g}$ & $10.9^{\mathrm{d}}$ & $19.0^{\mathrm{g}}$ & $0.0^{\mathrm{a}}$ & $0.0^{\mathrm{a}}$ & $0.0^{\mathrm{a}}$ & $8.1^{\mathrm{N}}$ \\
\hline $\begin{array}{c}\text { Potassium Bicarbonate + } \\
\text { Thiovit jet }\end{array}$ & $7.9^{\mathrm{c}}$ & $4.9^{\mathrm{b}}$ & $7.9^{\mathrm{c}}$ & $0.0^{\mathrm{a}}$ & $0.0^{\mathrm{a}}$ & $0.0^{\mathrm{a}}$ & $3.4^{\mathrm{L}}$ \\
\hline Potassium silicate & $19.7^{g}$ & $12.0^{\mathrm{d}}$ & $23.1^{\mathrm{i}}$ & $0.0^{\mathrm{a}}$ & $0.0^{\mathrm{a}}$ & $0.0^{\mathrm{a}}$ & $9.1^{\circ}$ \\
\hline Thiovit jet & $19.1^{\mathrm{g}}$ & $14.0^{\mathrm{de}}$ & $21.7^{\mathrm{h}}$ & $0.0^{\mathrm{a}}$ & $0.0^{\mathrm{a}}$ & $0.0^{\mathrm{a}}$ & $9.1^{\circ}$ \\
\hline Potassium bicarbonate & $23.1^{\mathrm{i}}$ & $12.3^{\mathrm{d}}$ & $25.1^{j}$ & $0.0^{\mathrm{a}}$ & $0.0^{\mathrm{a}}$ & $0.0^{\mathrm{a}}$ & $10.1^{\mathrm{P}}$ \\
\hline $\begin{array}{l}\text { Cooper ammonium } \\
\text { phosphate }\end{array}$ & $16.7^{\mathrm{f}}$ & $17.3^{\mathrm{f}}$ & $20.0^{\mathrm{g}}$ & $0.0^{\mathrm{a}}$ & $0.0^{\mathrm{a}}$ & $0.0^{\mathrm{a}}$ & $9^{\mathrm{O}}$ \\
\hline Mean cultivar & $19.5^{\mathrm{C}}$ & $14.7^{\mathrm{B}}$ & $22.0^{\mathrm{D}}$ & $0.0^{\mathrm{A}}$ & $0.0^{\mathrm{A}}$ & $0.0^{\mathrm{A}}$ & \\
\hline LSD 5\% cultivar & & & & $0.6-0.7$ & & & \\
\hline LSD 5\% treatment & & & & $0.7-0.8$ & & & \\
\hline LSD $5 \%$ int. cv. $\times$ tr. & & & & $1.8-2.3$ & & & \\
\hline
\end{tabular}

Table 3. Influence of different products used in organic apple growing on apple scab attack (AD\%) on fruits

\begin{tabular}{|c|c|c|c|c|c|c|c|}
\hline Treatment / Cultivar & 'Elstar' & 'Pinova' & $\begin{array}{c}\text { 'Golden } \\
\text { Delicious' }\end{array}$ & 'Luna' & 'Topaz' & 'Sirius' & Mean treatment \\
\hline Control & $33.3^{f}$ & $29.7^{\mathrm{e}}$ & $36.3^{f}$ & $0.0^{\mathrm{a}}$ & $1.7^{\mathrm{a}}$ & $0.0^{a}$ & $16.8^{\mathrm{P}}$ \\
\hline $\begin{array}{l}\text { Potassium bicarbonate + } \\
\text { Potassium silicate }\end{array}$ & $6.3^{\mathrm{bc}}$ & $5.9 \mathrm{~b}$ & $8.3^{\mathrm{c}}$ & $0.0^{\mathrm{a}}$ & $0.0^{a}$ & $0.0^{\mathrm{a}}$ & $3.4^{\mathrm{L}}$ \\
\hline Lime Sulphur & $11.0^{\mathrm{c}}$ & $7.3^{\mathrm{bc}}$ & $10.0^{\mathrm{c}}$ & $0.0^{\mathrm{a}}$ & $0.0^{\mathrm{a}}$ & $0.0^{\mathrm{a}}$ & $4.7^{\mathrm{LM}}$ \\
\hline $\begin{array}{c}\text { Potassium Bicarbonate + } \\
\text { Thiovit jet }\end{array}$ & $4.3^{b}$ & $2.6^{\mathrm{b}}$ & $6.5^{\mathrm{bc}}$ & $0.0^{\mathrm{a}}$ & $0.0^{a}$ & $0.0^{\mathrm{a}}$ & $2.2^{\mathrm{L}}$ \\
\hline Potassium silicate & $11.0^{\mathrm{c}}$ & $10.3^{c}$ & $18.3^{\mathrm{d}}$ & $0.0^{\mathrm{a}}$ & $0.0^{\mathrm{a}}$ & $0.0^{\mathrm{a}}$ & $6.6^{\mathrm{O}}$ \\
\hline Thiovit jet & $10.7^{c}$ & $10.3^{c}$ & $18.3^{d}$ & $0.0^{\mathrm{a}}$ & $0.0^{\mathrm{a}}$ & $0.0^{\mathrm{a}}$ & $6.6^{\mathrm{O}}$ \\
\hline Potassium bicarbonate & $11.3^{\mathrm{c}}$ & $10.7^{c}$ & $19.0^{\mathrm{d}}$ & $0.0^{\mathrm{a}}$ & $0.3^{\mathrm{a}}$ & $0.0^{\mathrm{a}}$ & $6.9^{\mathrm{O}}$ \\
\hline $\begin{array}{l}\text { Cooper ammonium } \\
\text { phosphate }\end{array}$ & $10.3^{\mathrm{c}}$ & $9.7^{\mathrm{c}}$ & $12.7^{\mathrm{c}}$ & $0.0^{\mathrm{a}}$ & $0.0^{\mathrm{a}}$ & $0.0^{\mathrm{a}}$ & $5.4^{\mathrm{MN}}$ \\
\hline Mean cultivar & $12.3^{\mathrm{C}}$ & $10.8^{\mathrm{B}}$ & $16.2^{\mathrm{D}}$ & $0.0^{\mathrm{A}}$ & $0.3^{A}$ & $0.0^{A}$ & \\
\hline LSD 5\% cultivar & & & & $1.0-1.1$ & & & \\
\hline LSD $5 \%$ treatment & & & & $1.1-1.3$ & & & \\
\hline LSD $5 \%$ int. cv. $\times$ tr. & & & & $2.7-3.5$ & & & \\
\hline
\end{tabular}

The current results seem to be in accordance with the results obtained by Jamar et al. (2010) who indicated that potassium bicarbonate significantly reduced apple scab severity on the leaves and fruits, while potassium silicate treatments did not reduce scab severity on leaves, but did reduce it very slightly on fruits.

Potassium bicarbonate treatment on multiple cultivars in field experiments in Romania significantly reduced foliar and fruit apple scab (Mitre et al., 2009, 2010).

The influence of different products against powdery mildew attack, on leaves

Power mildew control was more effective on the scab resistant cultivars than on the scab-susceptible ones (Table 4). Treatments with potassium bicarbonate + wettable sulphur induced the lowest degree of attack (2.5\%). Potassium bicarbonate and wettable sulphur used separately also reduced the attack on the leaves, but in the smaller scale.
As noted in previous studies (Holb et al., 2003; Jamar et al., 2008; Jamar et al., 2010)the treatments applied against apple scab and powdery mildew, after each rain, had several important advantages: no washing effect of products due to the rain; high effectiveness of treatments on spores in germinating phase; prevent new infections.

The efficiency of bicarbonate salts in controlling apple scab reported in previous studies (Schulze et al., 2003; Ilhan et al., 2006; Tamm et al., 2006; Jamar and Lateur, 2007; Jamar et al., 2007a, 2007b, 2008, 2010) suggests that this compound could be introduced in apple disease management, with the remark that is not to be used alone, but with other active compounds. Even bicarbonates seem to be effective against scab and powdery mildew, but a long lasting effect cannot be expected, because they are unstable compounds that are highly water-soluble and easily washed off the leaves by a small amount of precipitation (Jamar $e t$ al., 2010). 
Table 4. Influence of different products used in organic apple growing on apple powdery mildew attack (AD\%) on leaves

\begin{tabular}{|c|c|c|c|c|c|c|c|}
\hline Treatment / Cultivar & 'Elstar' & 'Pinova' & $\begin{array}{l}\text { 'Golden } \\
\text { Delicious' }\end{array}$ & 'Luna' & 'Topaz' & 'Sirius' & Mean treatment \\
\hline Control & $48.3^{g}$ & $29.7^{\mathrm{e}}$ & $36.3^{f}$ & $11.7^{c}$ & $7.0^{\mathrm{cb}}$ & $9.0^{c}$ & $23.7^{\mathrm{P}}$ \\
\hline $\begin{array}{l}\text { Potassium bicarbonate + } \\
\text { Potassium silicate }\end{array}$ & $6.3^{\mathrm{cb}}$ & $5.9^{\mathrm{b}}$ & $10.3^{c}$ & $1.4^{\mathrm{a}}$ & $1.4^{\mathrm{a}}$ & $1.8^{\mathrm{a}}$ & $4.5^{\mathrm{M}}$ \\
\hline Lime Sulphur & $11.0^{\mathrm{c}}$ & $7.3^{\mathrm{c}}$ & $10.0^{\mathrm{c}}$ & $1.5^{\mathrm{a}}$ & $1.0^{\mathrm{a}}$ & $0.7^{\mathrm{a}}$ & $5.2^{\mathrm{M}}$ \\
\hline $\begin{array}{c}\text { Potassium Bicarbonate + } \\
\text { Thiovit jet }\end{array}$ & $4.3^{\mathrm{b}}$ & $2.6^{a}$ & $7.9^{\mathrm{c}}$ & $0.0^{\mathrm{a}}$ & $0.0^{\mathrm{a}}$ & $0.0^{\mathrm{a}}$ & $2.5^{\mathrm{L}}$ \\
\hline Potassium silicate & $11.0^{\mathrm{c}}$ & $10.3^{c}$ & $18.0^{\mathrm{d}}$ & $4.0^{b}$ & $4.4^{b}$ & $3.7^{b}$ & $8.6^{\circ}$ \\
\hline Thiovit jet & $10.7^{\mathrm{c}}$ & $10.3^{\mathrm{c}}$ & $18.4^{\mathrm{d}}$ & $4.7^{b}$ & $4.7^{b}$ & $4.0^{\mathrm{b}}$ & $8.8^{\circ}$ \\
\hline Potassium bicarbonate & $11.3^{c}$ & $10.7^{c}$ & $19.0^{\mathrm{d}}$ & $4.8^{\mathrm{b}}$ & $4.8^{b}$ & $4.2^{b}$ & $9.1^{\circ}$ \\
\hline $\begin{array}{l}\text { Cooper ammonium } \\
\text { phosphate }\end{array}$ & $10.0^{3}$ & $9.7^{c}$ & $12.7^{\mathrm{c}}$ & $4.8^{\mathrm{b}}$ & $4.3^{\mathrm{b}}$ & $2.7^{a}$ & $7.4^{\mathrm{N}}$ \\
\hline Mean cultivar & $14.2^{\mathrm{C}}$ & $10.8^{B}$ & $16.6^{\mathrm{D}}$ & $4.1^{\mathrm{A}}$ & $3.4^{\mathrm{A}}$ & $3.3^{A}$ & \\
\hline LSD $5 \%$ cultivar & & & & $1.0-1.1$ & & & \\
\hline LSD 5\% treatment & & & & $1.1-1.3$ & & & \\
\hline LSD $5 \%$ int. cv. $\times$ tr. & & & & $2.8-3.5$ & & & \\
\hline
\end{tabular}

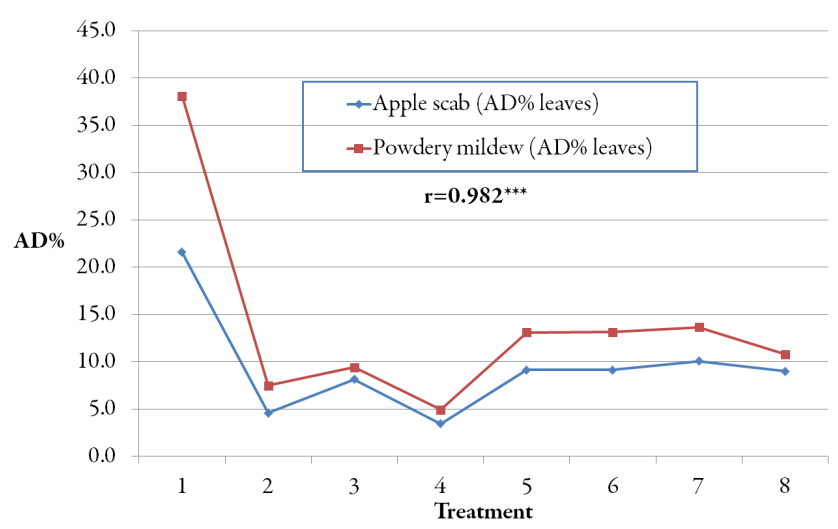

Fig. 3. Coefficient of correlation between apple scab and powdery mildew attack degree $(\mathrm{AD} \%)$ on leaves, as mean values of cultivars without genetic resistance to scab ('Elstar', 'Pinova', 'Golden Delicious'), depending on treatments: 1Control; 2-Potassium bicarbonate + Potassium silicate; 3Lime Sulphur; 4-Potassium Bicarbonate + Thiovit jet; 5Potassium silicate; 6-Thiovit jet; 7-Potassium bicarbonate; 8Cooper ammonium phosphate

Opposite to the current results, Cromwell et al. (2006) found that potassium bicarbonate was not as effective as the sulphur/lime sulphur treatment, in an experiment under Vermont conditions.

In the eight treatments of the experience against fungus diseases, the correlation between apple scab and powdery mildew attack degree $(\mathrm{AD} \%)$ on the leaves, as mean values of the cultivars without genetic resistance to scab ('Elstar', 'Pinova', 'Golden Delicious'), was very significant ( $\mathrm{r}=$ $0.982^{* * *} ;$ p $0.001=0.924$ ).

The influence of different products against powdery mildew attack, on yield

Data about the influence of bicarbonate salts and other alternative organic products with fungicide effect used in the experiment upon fruit yield in 2014-2016 are presented in the Table 5.
The results of Table 5 show that the yield was strongly affected by the studied diseases particularly in the case of scab susceptible cultivars: 'Elstar', 'Pinova' and 'Golden Delicious'. The yield of cultivars having resistance to scab and tolerance to powdery mildew was not affected, as the differences between them were not statistically assured. Besides, irrespective of the influence of cultivar, the effect of treatments was not significant upon yield except the variants of treatment with potassium bicarbonate + wettable sulphur, potassium bicarbonate and potassium silicate. Similar results were reported in some previous studies (Trapman, 2006; Jamar et al., 2010).

Several studies have shown that the repeated application of large amounts of sulphur compounds has eco toxicological and phytotoxic side-effects (Mills, 1947; Kreiter et al., 1998; Holb et al., 2003; Palmer et al., 2003).

Lime sulphur, wettable sulphur and cooper ammonium phosphates induced phytotoxicity on leaves and russeting on fruits, especially on 'Golden Delicious' cultivar.

Other authors also reported similar cases about phytotoxicity or foliar damage due to sulphur and copper treatments (Mills, 1947; Holb et al., 2003; Palmer et al., 2003).

\section{Conclusions}

Bicarbonate salts and other alternative organic products with fungicidal effect on apple cultivars, such as potassium bicarbonate, sulfur, potassium bicarbonate with sulfur, potassium bicarbonate with potassium silicate, potassium silicate, lime sulfur, cooper ammonium phosphate, significantly reduced attack grade of apple scab and mildew mildew on leaves and fruits and increased yield. Potassium bicarbonate used alone reduced apple scab and powdery mildew, being as effective as wettable sulphur, but was more effective in combination with wettable sulphur applied immediately after each rain. Mixture between potassium bicarbonate and potassium silicate was as effective as the mixture between potassium bicarbonate and wettable sulphur for reducing attack degree of apple scab and powdery mildew diseases, thus it can be concluded that 
120

Table 5. Influence of different products used in organic apple growing on apple yield $(\mathrm{kg} / \mathrm{tree})$

\begin{tabular}{|c|c|c|c|c|c|c|c|}
\hline Treatment / Cultivar & 'Elstar' & 'Pinova' & $\begin{array}{l}\text { 'Golden } \\
\text { Delicious' }\end{array}$ & 'Luna' & 'Topaz' & 'Sirius' & Mean treatment \\
\hline Control & $6.6^{c}$ & $9.7^{b}$ & $9.6^{b}$ & $10.2^{\mathrm{b}}$ & $11.0^{\mathrm{ab}}$ & $11.3^{\mathrm{ab}}$ & $9.7^{\mathrm{N}}$ \\
\hline $\begin{array}{l}\text { Potassium bicarbonate + } \\
\text { Potassium silicate }\end{array}$ & $9.3^{b}$ & $13.2^{a}$ & $11.9^{\mathrm{ab}}$ & $14.1^{a}$ & $11.7^{\mathrm{ab}}$ & $11.5^{\mathrm{ab}}$ & $12.0^{\mathrm{M}}$ \\
\hline Lime Sulphur & $7.4^{\mathrm{b}}$ & $9.9^{\mathrm{b}}$ & $10.6^{\mathrm{ab}}$ & $13.0^{\mathrm{a}}$ & $10.3^{\mathrm{ab}}$ & $10.3^{\mathrm{ab}}$ & $10.3^{\mathrm{N}}$ \\
\hline $\begin{array}{c}\text { Potassium Bicarbonate + } \\
\text { Thiovit jet }\end{array}$ & $13.1^{\mathrm{a}}$ & $13.4^{a}$ & $13.9^{\mathrm{a}}$ & $14.3^{\mathrm{a}}$ & $12.3^{\mathrm{a}}$ & $11.8^{\mathrm{ab}}$ & $13.1^{\mathrm{L}}$ \\
\hline Potassium silicate & $9.5^{b}$ & $9.3^{\mathrm{b}}$ & $9.5^{b}$ & $13.7^{\mathrm{a}}$ & $11.0^{\mathrm{ab}}$ & $11.0^{\mathrm{ab}}$ & $10.7^{\mathrm{N}}$ \\
\hline Thiovit jet & $9.2^{b}$ & $9.5^{b}$ & $9.3^{b}$ & $13.0 \mathrm{a}$ & $10.9^{\mathrm{ab}}$ & $10.7^{\mathrm{ab}}$ & $10.4^{\mathrm{N}}$ \\
\hline Potassium bicarbonate & $8.9^{\mathrm{b}}$ & $9.4^{b}$ & $9.5^{b}$ & $11.0^{\mathrm{ab}}$ & $11.1^{\mathrm{ab}}$ & $11.0^{\mathrm{ab}}$ & $10.2^{\mathrm{N}}$ \\
\hline $\begin{array}{l}\text { Cooper ammonium } \\
\text { phosphate }\end{array}$ & $8.8^{\mathrm{b}}$ & $9.7^{\mathrm{b}}$ & $9.3^{\mathrm{b}}$ & $11.0^{\mathrm{ab}}$ & $10.9^{\mathrm{ab}}$ & $11.0^{\mathrm{ab}}$ & $10.1^{\mathrm{N}}$ \\
\hline Mean cultivar & $9.1^{\mathrm{C}}$ & $10.5^{\mathrm{B}}$ & $10.5^{\mathrm{B}}$ & $12.5^{\mathrm{A}}$ & $11.2^{\mathrm{B}}$ & $11.1^{\mathrm{B}}$ & \\
\hline LSD 5\% cultivar & & & & $1.0-1.2$ & & & \\
\hline LSD $5 \%$ treatment & & & & $1.2-1.4$ & & & \\
\hline LSD $5 \%$ int. cv. $\times$ tr. & & & & $3.0-3.8$ & & & \\
\hline
\end{tabular}

potassium silicate potentiates the action of potassium bicarbonate. Wettable sulphur proved to be less effective in scab and powdery mildew control than lime sulphur. The advantage displayed by cooper ammonium phosphate is the efficiency, similar or better, to the potassium silicate, wettable sulphur and potassium bicarbonate, with a cooper doses of ten times lower per hectare, meaning lower price for attack control and longer lasting effect.

\section{Acknowledgements}

This work was supported by the Institute of Advanced Horticulture Research of Transylvania, University of Agricultural Sciences and Veterinary Medicine ClujNapoca.

\section{References}

Bahraminejad S, Asenstorfer RE, Riley IT, Schultz CJ (2008). Analysis of the antimicrobial activity of flavonoids and saponins isolated from the shoots of oats (Avena sativa L.). Journal of Phytopathology 156:1-7.

Bengstsson M,Wulff E,Lyngs Jørgensen HJ,Pham A,Lübeck M, Hockenhull J (2009). Comparative studies on the effects of a yucca extract and acibenzolar-S-methyl (ASM) on inhibition of Venturia inaequalis in apple leaves. European Journal of Plant Pathology 124:187-198.

Burrell AB (1945). Practical use of our newer knowledge of apple scab control. Proceedings of the 90th Annual Meeting of the New York State Horticultural Society 90:9-16.

Creemers P, Van Laer S, Van Mechelen A, Vorstermans B, Hauke K (2006). Evaluation of the users value of salts against apple scab and powdery mildew for the integrated fruit production. Communications in Agricultural and Applied Biological Sciences 72(4):917-923.

Cromwell ML, Berkett LP, Darby HM (2011). Alternative organic fungicides for apple scab management and their non-target effects. HortScience 46(9):1254-1259.
Dan C, Sestras AF, Bozdog C, Sestras RE (2015). Investigation of wild species potential to increase genetic diversity useful for apple breeding. Genetika 47(3):993-1011.

Environmental Protection Agency (2006). Toxicity categories and pesticide label statements. Retrieved 2017 February 02 from http:// www.epa.gov/pesticides/health/tox_categories.

Gessler C, Patocchi A, Sansavini S, Tartarini S, Gianfranceschi L (2006). Venturia inaequalis resistance in apple. Critical Reviews in Plant Sciences 25:473-503.

Heijne B, de Jong PF, Köhl J, Speksnijder AG, Hockenhull J, Bengtsson M, ... Trapman M (2006). Prevention and control of apple scab. In: Proceedings of the European Joint Organic Congress "Organic farming and rural development", Odense, Denmark. Retrieved 2017 March 15 from http://orgprints.org/7781/1/applescabBHeijne.pdf.

Holb IJ (2008). Timing of first and final sprays against apple scab combined with leaf removal and pruning in organic apple production. Crop Protection 27:814-822.

Holb IJ, De Jong PF, Heijne B (2003). Efficacy and phytotoxicity of lime sulphur in organic apple production. Annals of Applied Biology 142:225-233.

Holb IJ, Heijne B, Jeger MJ (2005). Analysis of summer epidemic progress of apple scab at different apple production systems in the Netherlands and Hungary. Phytopathology 95:1001-1020.

Ilhan K, Arslan U, Karabulut OA (2006). The effect of sodium bicarbonate alone or in combination with a reduced dose of tebuconazole on the control of apple scab. Crop Protection 25:963967.

Jamar L, Cavelier M, Lateur M (2010). Primary scab control using a "during-infection" spray timing and the effect on fruit quality and yield in organic apple production. Biotechnologie, Agronomie, Société et Environnement 14(3):423-439.

Jamar L, Lateur M (2007a). Strategies to reduce copper use in organic apple production. Acta Horticulturae 737:113-120.

Jamar L, Lefrancq B, Fassotte C, Lateur M (2008). A during-infection 
spray strategy using sulphur compounds, copper, silicon and a new formulation of potassium bicarbonate for primary scab control in organic apple production. European Journal of Plant Pathology 122(4):481-493.

Jamar L, Lefrancq B, Lateur M (2007b). Control of apple scab (Venturia inaequalis) with bicarbonate salts under controlled environment. Journal of Plant Diseases and Protection 114(5):221-227.

Köhl J, Kassemeyer HH, Tamm L, Gessler C, Pertot I, Bertrand C, ... Trapman M (2004). Replacement of copper fungicides in organic production of grapevine and apple in Europe (REPCO). S. Michele all'Adige, Italy, 27(8):191.

Kreiter S, Sentenac G, Barthes D, Auger P (1998). Toxicity of four fungicides to the predacious mite Typhlodromuspyri (Acari: Phytoseiidae). Journal of Economic Entomology 91:802-811.

MacDaniels LH, Furr JR (1930). The effect of dusting-sulfur upon the germination of the pollen and the set of the fruit of the apple. Bulletin Cornell University Agricultural Experiment Station 499:113.

MacHardy WE (1996). Apple scab, biology, epidemiology and management. St Paul, MI, USA: APS Press.

Marku L, Vrapi H, Hasani M (2014). Effect of potassium bicarbonate (Armicarb) on the control of apple scab (Venturia inequalis) in the region of Puka in Albania. International Refereed Journal of Engineering and Science 3(6):25-30.

Marloth RH (1931). The influence of hydrogen-ion concentration and of sodium bicarbonate related substances on Penicillium italicum and $P$. digitatum. Phytopathology 48: 169-181.

McArtney S, Palmer J, Davies S, Seymour S (2006). Effects of lime sulfur and fish oil on pollen tube growth, leaf photosynthesis and fruit set in apple. HortScience 41:357-360.
Mills WD (1947). Effects of sprays of lime sulphur and of elemental sulphur on apple in relation to yield. Cornell University Agricultural Experiment Station.

Mitre I, Mitre V, Sestras R, Pop A, Sestras A (2010). Contributions to development of new products against apple scab for organic apple production. Bulletin UASMV Horticulture 67(1):127-131.

Mitre I, Mitre V, Sestras RE, Pop A, Sestras A (2009). Potassium bicarbonate in preventing and control apple scab. Bulletin UASMV Horticulture 66(1-2):186-190.

Mitre V, Mitre I, Sestras A, Sestras R (2010). New products against apple scab and powdery mildew attack in organic apple production. Notulae Botanicae Horti Agrobotanici Cluj-Napoca 38(3):234 238.

Palmer JW, Davies SB, Shaw PW, Wünsche JN (2003). Growth and fruit quality of 'Braeburn' apple (Malus domestica) trees as influenced by fungicide programmes suitable for organic production. New Zealand Journal of Crop and Horticultural Science 31:169-177.

Schulze K, Schönherr J (2003). Calcium hydroxide, potassium carbonate and alkyl polyglycosides prevent spore germination and kill germ tubes of apple scab (Venturia inaequalis). Journal of Plant Diseases and Protection 110:36-45.

Sestras AF, Pamfil D, Dan C, Bolboaca SD, Jäntschi L, Sestras RE (2011). Possibilities to improve apple scab (Venturia inaequalis (Cke.) Wint.) and powdery mildew [Podosphaera leucotricha (Ell. et Everh.) Salm.] resistance on apple by increasing genetic diversity using potentials of wild species. Australian Journal of Crop Science 5(6):748-755. 